\title{
The Influence of Discipline on Lecturers' Motivation and Performance in Indragiri College of Economics (STIE) Rengat
}

\author{
Ivalaina Astarina*a $^{* a}$ Angga Hapsila ${ }^{b}$, Tomy Fitrio ${ }^{c}$ \\ a: Indragiri College of Economics (STIE-I) Rengat \\ b: Indragiri College of Economics (STIE-I) Rengat \\ c: Indragiri College of Economics (STIE-I) Rengat
}

\begin{abstract}
This research aimed to determine the influence of discipline on motivation, as well on lecturers performance, and to discover the influence of motivation on the lecturers' performance in Indragiri College of Economics (STIE) Rengat. The researchers took the population of the lecturers in Indragiri College of Economic (STIE-I) Rengat. The numbers of the lecturers in Indragiri College of Economics (STIE) Rengat were 34 people. The sampling method of this research was using a saturated sampling technique (census). The data of this research were analyzed by using quantitative method and all obtained data were processed by PLS. The results of this research showed that discipline had significant influence on motivation, as well on the lecturers' performance; subsequently the motivation had influence on the lecturers' performance and discipline had influence on the lecturers'performance which was mediated by motivation.
\end{abstract}

Key Words: Discipiline, Motivation, and Performance

\section{Introduction}

In Kabupaten Indragiri Hulu, there are currently 10 (ten) Private Colleges (PTS) including Indragiri College of Economics (STIE-I) Rengat. With the increasing number of tertiary institutions, the level of competition is certainly getting tougher. Therefore, as an official institution, the Indragiri College of Economics (STIE-I) Rengat certainly hopes that every lecturer can give his/her best performances so that the Indragiri College of Economics (STIE-I) Rengat is able to win the competition. The lecturers who have good performance will certainly be able to carry out the tasks that have been charged to them effectively and efficiently and they are able to resolve any obstacles and problems encountered. Performance according to Hamali (2016:98) is the result of work that has a strong relationship with the organization's strategic goals, customer satisfaction and can contribute to the economy.

Discipline attitudes are required to take the organization achieving its goals quickly because the discipline drives everyone involved to be able to obey every rule and policy that is made and do the work responsibly. Hasibuan (2013: 193) gives an understanding of discipline that is the awareness and willingness of someone to obey all applicable rules and social norms. Since discipline teaches people to accomplish work on time, a disciplined person certainly will not neglect every task given to them. Discipline is one of the six values instilled by the academic community.

The motivation shown by each lecturer is not the same. There are lecturers who have high motivation and there are also lecturers who have low motivation. For this reason, we need tips to increase low motivation so that the set goals can be achieved properly. Motivation, according to Mangkunagara (2014: 61), is formed by the employees' attitudes in facing work situation in the company. Motivation is the condition or energy that moves employees who are directed towards achieving the goals of the company's organization. According to the result of the research by Rianiningsih and Triyaningsih, it was obtained that the results of discipline variables had no significant influences on work motivation. Then, according to Mensah and Tawiah (2016), the result of the study showed that a one-way variance analysis was conducted to determine whether extrinsic motivation had an impact on performance using education levels of the employees sample 
from four mining companies or not. The results showed that there were no significant differences in scores on extrinsic motivation in relation to education level of the employees. The performance of employees decreased due to many reasons, such as the applied leadership, the culture of organization, poor work motivation, job satisfaction and so on. Therefore, it is required high motivation with various forms and ways to create effective and efficient performance (Salih, 2018: 11).

Based on these cases, the authors examined "The Influences of Discipline on Lecturers Motivation and Performance in Indragiri College of Economics (STIE-I) Rengat". The formulations of the problem are:

a. Does discipline have influence on motivation in Indragiri College of Economics (STIE-I) Rengat?

b. Does discipline have influence on lecturers performance in Indragiri College of Economics (STIE-I) Rengat?

c. Does motivation have influence on lecturers performance in Indragiri College of Economics (STIE-I) Rengat?

\section{$2 \quad$ Literature Review}

\section{$2.1 \quad$ Performance}

When we look at the meaning of the word "performance" in the Great Dictionary of Indonesian (KBBI), it is something that is achieved, work performance shown or the ability to work (about equipment). According to experts, the definitions of performance are:

Employee performance (work performance) is the result of work both in quality and quantity achieved by an employee in carrying out his duties in accordance with the responsibilities given to him. (Mangkunegara, 2014: 9).

According to Benardin and Russel, performance is a record of the results obtained from the function of a particular job or activity during a certain period of time.

Performance is the result of work that can be achieved by a person or group of people in an organization, in accordance with their respective authorities and responsibilities, in order to achieve the objectives of the organization concerned legally, does not violate the law and in accordance with morals and ethics. (Prawirosentono and primasari, 2015: 2)

Performance is the result of work that has a strong relationship with the organization's strategic goals, customer satisfaction and gives contribution to the economy. (Hamali, 2016:98)

There are several important objectives of a program performance asssestment that cannot be achieved by other methods. The main purpose of a performance assesment system is to produce accurate and valid information about the behavior and performance of organization members. The more accurate and valid information that is produced by a performance assessment system, the greater its potential value for the organization will be (Simamora, 2004: 343).

The purpose of performance evaluation is to elevate or improve the organization performance through improved performance of the HR organization. More specifically, these are the objectives and performance evaluation as stated by Agus Sunyoto (1999) in Mangkunegara (2014: 10):

a) Improving a mutual understanding among employees about performance requirements.

b) Recording and admitting the work results of an employee, so that they are motivated to perform better, or at least they get achievements equal to the previous performance.

c) Providing opportunities for employees to discuss their desires and raising awareness of the career or work they are carried out now.

d) Defining or redefining future goals, so that the employees are motivated to get achievements according to their potential.

e) Examining the implementation and development plan that is appropriate to the training needs, specifically the training plan and then approving the plan if there are no things that need to be changed.

Generally, the process of performance assessment can be carried out with these following stages: (Wukir, 2013: 106)

a) Measuring the actual performance. The most difficult thing in the process of performance assessment is measuring the actual performance of employees which is the work that has been carried out by the 
employees for a certain period of time. This stage requires the selection of appropriate assessment methods and must be performed carefully. In addition, it must also be considered that personal biases may not influence the results of the process and the assessment should not affect the employees' performance.

b) Comparing the actual performance with the expected. The actual performance is compared by the set performance standars. The comparison will exhibit deviations in employees' performance from the standards set.

c) Discussing the results. The results of performance assessment are then communicated and discussed with the employees. Creating the special meeting with the involved employees. Pointing out that the purpose of the meeting is to provide feedback and to make a work plan. While the discussion is going on, give the opportunity to the employees to speak out their intentions and responses by giving suggestion then discuss the things that are not consentaneous.

The purposes of performance assessment are: (Mangkunegara, 2014:11)

a) As a basis to make decision used for achievement, dismissal, and the amount of remuneration.

b) To measure how far an employee can accomplish his work.

c) As a basis to evaluate the effectiviness of all activities in the company.

d) As a basis to evaluate training program and the effectivity of working schedules, working methods, organizatio structures, supervision styles, working conditions and controls.

e) As an indicator to determine the needs of training for employees within the organization.

f) As a tool to improve the employees motivation in order to achieve good performance.

g) As a tool to see the weekness and improve the ability of the next employees.

h) As a criteria to determine the selection and placement of the employees.

i) As a tool to improve or develop the employees' skills.

j) As a basis to improve or develop job description.

The approaches in the system of employees' performance assessment can be categorized into four types: (Hamali, 2016: 121-123)

1. Personal traits approach

Classical performance evaluation uses personal traits approach. Personal traits that are assessed are related to work only.

2. Work results approach

In this approach, every employee has goals and objectives that he has to achieve. The employees' performance is assessed based on how much an employee can achieve those goals.

3. Work behaviors approach

In this approach, an employee has to use certain behaviours and procedures and cling to the professional ethic code that regulates work behaviours.

4. Mixed approach

The mixed approach of performance assessment system is the most widely used approach. This approach combines the three performance dimensions into employee performance's indicators. The work indicator used is a mixture of these three dimensions in the form of a percentage

The performance assessment can bring erroneous results when the assessor is biased or the standard of evaluation is unclear. The errors of performance assessment that are commonly found are: (Simamora, 2004: 351-356)

a. Leniency

Inexperienced or bad supervisors may decide on the easiest way to assess performance that by giving a high evaluation value to everyone. The best employee in the department will complain about such supervisors because the hard-working people do not get more value than those who do not work hard. Such biased of generosity is not desirable because it causes employees looked more competent than the real fact.

b. Strictness

Sometimes supervisor gives lower values consistently although some employees may have reached an average or above average level of performance. The tightness problem is the reversibility of the 
generosity problem. The failure of providing acknowledgment when performing assessment that they are entitled can quickly lead to a serious rift in the supervisor-subordinate relationship.

c. Central Tendency

Supervisors may find it difficult and inconvenient to evaluate some employees who are partially higher or lower than others, even though their performances show the significant differences. The problem of centralized tendencies sticks out when supervisor evaluates each person on average. Central Tendency Issues also occurs when supervisor cannot objectively evaluate the performance of employees due to a lack of familiarity with their work, lack of supervisor skills or the fear that they will be reviled if they evaluate individuals too low.

d. Hallo Effect

Hallo effect appears when a supervisor gets used to one particular aspect of the employee's performance affecting other aspects being evaluated. Because of the hallo effect, evaluator gives an employee the same scores for all factors, regardless of the actual performance of the employee.

e. Biased Supervisor

The most common mistake in any method of assessment is awareness or unconsciousness of biased supervisor. The bias is not related to the implementation of work and can lead to personal characteristics such as age, gender, sense of characteristics related to organizations such as the seniority of membership in an athletic team or the company's close relationship with top management.

f. Recency

Ideally the assessment of employees' performance must be based on systematic observation of employee performance throughout the entire assessment period (generally one year). Unfortunately, when organizations use annual or mid-year performance assessments, there is a tendency of supervisors to remember more about everything that is done by employees compared to what was done a few months before.

g. Organization Influences

Basically, the assessment tends to take into account the ultimate usefulness of the assessment data when the assessor is assessing his subordinates. If they believe that promotions and pay hike depend on the value of performance, they tend to give high value (judgment is loose).

h. Evaluation Standard

The evaluation standard issues appear because of the conceptual differences in the meaning of words used to evaluate employees. Thus the words "good, adequate, satisfying and amazing" attain to have different meanings for each evaluator. If there is only an evaluator who is used, evaluation is able to deviate. This difficulty often arises in graphic rating scale techniques, but it can also appear in essay techniques, critical events and questionnaires.

The performance of a workforce or employee in an organization or work institution is influenced by many factors, factors of the employees themselves as well as environmental factors or work organization itself. According to Gibson (1977) the factors that determine an individual's performance, are categorized into three main factors: (Notoatmodjo, 2009: 124-125)

a) Individual variables, consisting of: understanding of his work, working experiences, family background socio-economic level and demographic factors (age, sex, ethnicity, etc.).

b) Organization variables, consisting of: leaderships, job designs, and other resources: organizational structures and so on.

c) Psychological variables, consisting of work perceptions, attitudes toward work, motivation, personality and so on.

The indicators of work performance in Hamali (2016:119) are:

1. The Result of Work

2. Work Knowlegde

3. Initiative

4. Mental Dexterity

5. Attitudes 


\section{Time and Attendance Disciplines}

\subsection{Motivation}

What is meant by motivation in the Great Dictionary of Indonesian (KBBI), is encouragement that arises in a person consciously or unconsciously to perform an action with a certain purpose or effort that can cause a person or group of people turn a finger to do something because they want to achieve their desired goal or to have satisfaction of their actions. At the same time, the definitions of motivation according to experts are:

According to Berelson and Steiner, motivation is a conscious effort to influence a person's behavior to set in achieving the organization goals. (Sunyoto, 2013:192)

Motivation is an encouragement that will create a behavior in order to achieve satisfaction. (Suwatno dan Priansa, 2014:172)

The definition of motivation as formulated by Tery G (1986) is a desire that comes in individual person encouraging him to do actions (behavior). (Notoaatmodjo, 2009: 114)

Motivation can be defined as a process that describes the intensity, direction and perseverance of a person in attempting to reach his goal. (Wukir, 2013: 115)

Motivation comes from Latin word (movemore) which means encouragement or movement. Motivation in management is only aimed in human resources generally and subordinates particularly. Motivation questions how to mobilize subordinates' potencial, so that they want to work together productively succeed in achieving and realizing their intended goals (Hasibuan, 2013: 141)

According to Armstrong, there are various motivation approaches or theories that attempt to investigate the process of motivation and explain why people take certain actions at workplace. The process of motivation is something complex. Everyone is unique, has different needs and goals, and also takes different actions to achieve his goals. The practice of motivation can work effectively when it is based on sufficient understanding of the components involved. The model of the motivational process is shown in the figure below. (Wukir, 2013: 116-117

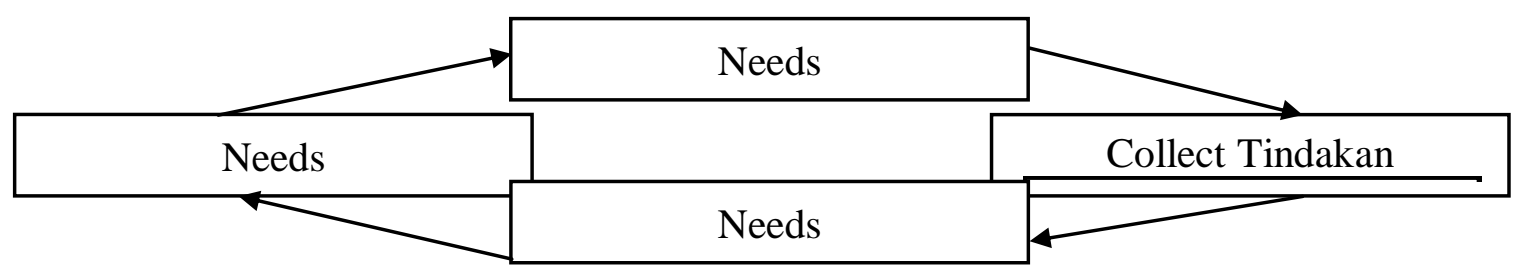

Picture 1

Motivation Process

This model shows that motivation is initiated by the needs which are not fulfilled either consciously or unconsciously. This need creates desire to achieve or get something. Thereupon, it is created a purpose that can satisfy a need and behavior which are presumably able to achieve that goal. If the goal is reached, it means that the need is fulfilled and this behavior will be repeated again when the same need reappears. If the goal is not reached, this action will not be repeated anymore.

Here are some motivation theories:

1. Needs Theory (Hierarchy). According to Maslow, quoted by Malayu S.P Hasibuan (2013:154), the factors that influence work motivation are:

a. Physiological Needs. The needs to maintain life are including food, drink, housing, air, and so on. The desires to fulfill this needs stimulate people to behave and work hard.

b. Safety and Security Needs. The needs for freedom of threats are a sense of security from the threat of accidents and safety in carrying out work. This needs set into two forms; they are the 
need for mental security, especially the security of the life in the workplace while they are doing their job and the need for security of property in the workplace while they are working.

c. Affiliation or acceptance Needs; Social needs, friend affiliation, interaction, love and being loved, and socially acceptable in society groups of workers and the environment. Basically, humans do not want to live alone in a remote place, they always need group life.

d. Esteem or Status Needs; the need for self-esteem and acknowledgement and appreciation of prestige from employees and the society. Ideally prestige arises because of the achievement, but it does not always so. However, it should also be considered by the leader that the higher position of someone in society or in the organization hence the higher his prestige. Prestige and status are manifested by many things that are used as status symbols.

e. Self Actualization Needs; The needs for self-actualization by using ability, skill and optimal potential to achieve very satisfying work performance. This need is a complete realization of one's potential fully. The desire of someone to achieve his needs completely can be different from one another; the company leader can fulfill the needs by organizing education and training.

2. Achievement Theory. Mc. Clelland's Achivement cited (Hasibuan, 2013:162-163) argues that employees have energy reserves which are released and used depending on someone's strengthmotivation encouragment from the situation and the available opportunities. This energy is utilized by the employees because it is driven by:

a. Motives strength and basic needs involved.

b. Success Expetation.

c. Incentive value that is attached to the goal

The things that can motivate people are:

a. Need for achievement. It is a driving force that encourages someone to have motivation in working. Therefore, the need for achievement will encourage someone to develop his creativity and direct all of his abilities and energies in order to achieve his maximum work performance.

b. Need for affiliation. It is a driving force to motivate someone's enthusiasm to work. Therefore, the need for affiliation will stimulate the employee's enthusiasm in working.

c. Need for power. It is a driving force to motivate the employees' spirit to work. Need for power excites and motivates employee's spirit and directs all of his abilities to achieve the power or the best position. The ego of people who want more power will generate competition.

3. Claude S. George's Motivation Theory. That someone has needs related to the place and circumstances in the environment he works, Malayu S. P Hasibuan (2013: 163), namely:

a. Fair and proper wages

b. Opportunity to be progressive / promotion

c. Acknowlegdment as an individual

d. Work security

e. Good workplace

f. Acceptance by groups

g. Reasonable treatment

h. Acknowlegdment of achievement

Giving motivation to the employees is an obligation of the leaders, so that these employees can further increase the volume and quality of work that is being their responsibility. Therefore, a leader has to pay attention to these following matters so that the provision of motivation can succeed as expected. (Sutrisno, 2010: 144-146)

a) Understanding the behavior of subordinates

A leader must be able to understand the behavior of subordinates, it means that a leader in the overall task should be able to pay attention, observes the behaviors of his subordinates. By understanding his employees' behaviors, a leader will be easier to motivate them in working.

b) Must act and behave realistically 
A leader knows that the abilities of his subordinates are not the same, so that he can provide tasks that are roughly the same as their respective abilities. In providing motivation, subordinates must use logical considerations and can be executed by subordinates.

c) The level of each person's needs is different

The level of each person's needs is not the same due to the presence of tendency, desires, feelings and expectations that differ between one person and another at the same time.

d) Able to use skills

A desired leader can be a pioneer in everything. He is expected to govern the ins and outs of the job, he has his own tips to solve the problem, especially problems faced by subordinates in carrying out their duties.Therefore, they are required to use their skills: creating a pleasant working circumstances, giving awards and compliments for their achievement and lead by the hand for those who are not achieved yet, dividing tasks according to the subordinates' abilities, and giving feedback on the work and providing an opportunity for subordinates to be progressive and creativity.

e) Giving motivation must refer to people

Motivation is given for people or employees personally and not for the leader. A leader should treat a subordinate as a subordinate, not as himself who is having high awareness to perform a good work.

f) Must be able to be exemplary

An exemplary is the best teacher; it is not useful one thousand words if a person's actions do not portray it. People will not respect or have sympathy to the leader who has big mouth, but he cannot commit to what he said.

While in Hamali (2016: 140-141), the principles in motivating employees' work, are:

a) The principle of participation. In motivating work, the employees need to be given opportunity to participate in determining the goals that leader wants to achieve.

b) The principle of communication. The leader communicates everything related to the effort of achieving the task, and by giving clear information the employees will be more easily motivated to work.

c) The principle of admitting the subordinates' contribution. The leader acknowledges that subordinates have contribution in achieving goals. The employees will be more easily motivated by this acknowledgment.

d) The principle of authority delegation. The leader giving authority to the subordinate employees at any time in order to make decisions on the work they do - will make the concerned employees become motivated to achieve the goals that are expected by the leader.

e) The principle of paying attention. The leader paying attention on what his subordinate employees want will motivate employees to work as expected by the leader.

These are the indicators of work motivation according to Noor dan Gofur (2009:156):

1. The desires to have achievement.

2. The desires to make improvements.

3. The desires to make changes.

4. The desires to always improve the work ability.

5. The desires to have work knowledge

\subsection{Diciplines}

Discipline in the Great Dictionary of Indonesian (KBBI is an order (in school, military, etc.), is an obedience to the regulations (order and so on), fields of study that have certain objects, systems, and methods.

The definitions of discipline according to experts are:

According to Singodimedjo (2002) cited by Sutrisno (2010: 86) discipline is the attitude of someone's willingness and compliance to abide and obey the norms of regulations prevailing around it.

According to Sinungan (2009: 145) that: "Disciplin of work is a mental attitude that is reflected in the actions or behavior of individuals, groups or people in the form of obedience to the regulations or provisions set by the government or ethics, norms and rules prevailing in society for certain purposes. " 
In the Dictionary of Education, Good's express the definition of discipline: (Wukir, 2013: 92-93)

1. The process or results of desires' directing and controlling, encouragements or interests in order to achieve the purpose or to attain more concise action.

2. Looking for the selected action by the tenacious, active and self-directed, even though facing the obstacles.

3. Controlling the behavior directly and have authoritarian with the punishments and rewards.

4. Restrainting of encouragement in an uncomfortable way and even painful.

The discipline of employee is the behavior of someone according to the rules, the existing work procedures or discipline is the attitudes, behaviors and actions that are in accordance with the rules of the organization, both written and unwritten. A good form of discipline will be reflected in the circumstances as: (Hamali, 2016: 215)

1. The high caring sense of employees towards achieving company goals.

2. The high enthusiasm, passion and iniative of employees to perform work.

3. The considerable of employees' responsibility to carry out the duties properly.

4. The development of belonging sense and high solidarity among the employees.

5. The increasing of employees' efficiency and work productivity.

According to Singodimedjo, the factors that influence employee's discipline are: (Sutrisno: 2010: 89-92)

a) The amount of compensation

The amount of compensation is able to influence the enforcement of discipline. The employees will obey the rules if they think that they get guarantee of remuneration for efforts that have been contributed to the company. If they obtain adequate compensation, they will be able to stay calm and diligent at work and always try to work as well as possible.

b) The presence of leader exemplary in the company

Leader exemplary is very important, because in a company environment, all employees will pay attention on how the leader can enforce his own discipline, and how he can control himself from words, actions and attitudes that can harm the discipline rules set. The role of exemplary leader is very influential in the company; even it is very dominant compared to all the factors that influence discipline in the company, because a leader in the company is still role model for the employees.

c) The presence of certain rules that are used as a guidance

The development discipline cannot be carried out in the company if there are no definitely written rules to rely on together. Discipline can not be enforced when the rules are made solely based on verbal instructions that can change according to conditions and situations. The employees want to be discipline when there are clear regulations and they are informed to the employees. If the rules of discipline are only according to the leader's willing, do not expect that the employees will fulfill these rules.

d) The leader intrepidity in taking actions

If there is an employee who breaks he discipline, it is necessary that a leader has courage to take action in accordance with the level of the offense he made. By giving an action of discipline offense, in accordance with the existing sanction, all employees feel protected and promise that they will not do the same thing. In this way, all employees will truly avoid being reckless, as long as they are arbitrary in the company.

e) The precense of Leader's supervision

In every company activities there needs supervision that will drives the employees to carry out the work appropriately and according to established rules. However, it has also become human nature that they always want to be free, without being bound or bound by any rules. With such supervision, more or less, employees will be accustomed to implement work discipline. The most appropriate person in performing this supervision is certainly the direct supervisor of those employees. This is because the direct supervisor is the one who knows the best and closer to his subordinates. Supervision carried out by the direct supervisor is often called WASKAT.

f) The presence of employees attention

Employees are humans who have different characters from one another. An employee is not only satisfied with receiving high compensation, or challenging work but they also still need great 
attention from their own leader. Their complaints and difficulties want to be heard, and find solutions and so on. Leaders who succeed in giving great attention to their employees will be able to create good work discipline.

g) Created habits that drives discipline

Poor leaders, who use their power arbitrarily, will use continuous threats, sometimes able to look good in discipline, but feel anxious and uneasy arising from strict regulations and any coercion, able to blow up any time in front of the leader. With good leadership, a leader can do lot things to create a work climate that enables enforcement of discipline as a reasonable process, because employees will accept and comply the regulations and policies as a protector for the success of their work and personal welfare.

Education is better than punishment and constructive correction is better than excoriation, is the key of the overall program individual improvement program that have to be a pressure in implementing discipline. A constructive discipline program must be developed by around these elements: (Sutrisno, 2010: 94-95)

1. The formulation of the provisions is clear, reasonable regulations, published and implemented carefully.

2. The implementation is fair by using warnings and laws that are declared, with the aim of providing corrections, balanced with violations, not strict at the beginning and set uniformly.

3. The supervisory leadership is adjusted to the rules of discipline and procedures, attentive but firm in dealing with disciplinary issues, and supervisory leadership itself is an example for employee behavior.

4. The implementation which is fair and similar for the visible investigation depends on higher management level reviews, including how to appeal against disciplinary decisions that are deemed unfair.

The indicators of discipline according to Hasibuan (2013: 194) are:

1. Purpose and Ability

2. The Exemplary Leadership

3. Remuneration

4. Justice

5. Waskat

6. Penalty / Punishment

7. Firmness

8. Human relationship

\section{$2.4 \quad$ Previous Research}

Previous research about the influence of Discipline on Lecturer Motivation and Performance can be seen in table 1 below:

Table 1: Previous Research about Discipline on Motivation and Performance.

\begin{tabular}{|l|l|l|l|}
\hline No. & \multicolumn{1}{|c|}{ Author (year) } & \multicolumn{1}{|c|}{ Variable } & \multicolumn{1}{c|}{ Result } \\
\hline 1 & $\begin{array}{l}\text { (U. Rinaldi, } \\
\text { 2016) }\end{array}$ & $\begin{array}{l}\text { Dicipline } \\
\text { Work Ethic } \\
\text { Organization Circumstance } \\
\text { Performance }\end{array}$ & $\begin{array}{l}\text { Discipline - Performance Significant } \\
\text { Work Ethic - Performance Significant } \\
\text { Organization Circumstance - Performance } \\
\text { Significant }\end{array}$ \\
\hline 2 & $\begin{array}{l}\text { Ainun Jariah } \\
(2016)\end{array}$ & $\begin{array}{l}\text { Work Ethic } \\
\text { Compentations } \\
\text { Disciplinary } \\
\text { Performance }\end{array}$ & $\begin{array}{l}\text { Work Ethic - Performance Not Significant } \\
\text { Financial Compentations - Performance } \\
\text { Significant } \\
\text { Non Financial compentation - Performance } \\
\text { Not Significant } \\
\text { Disciplinary - Performance Significant }\end{array}$ \\
\hline 3 & $\begin{array}{lll}\text { (M. Rinaldi, } \\
\text { 2016) }\end{array}$ & $\begin{array}{l}\text { Work Discipline } \\
\text { Work Ethic } \\
\text { Situational Leadership }\end{array}$ & $\begin{array}{l}\text { Work Ethic - Performance Significant } \\
\text { Situational leadership - Performance Not }\end{array}$ \\
\hline
\end{tabular}




\begin{tabular}{|c|c|c|c|}
\hline & & Performance & Significant \\
\hline 4 & $\begin{array}{l}\text { (Timbuleng \& } \\
\text { Sumarauw, } \\
\text { 2015) }\end{array}$ & $\begin{array}{l}\text { Work Ethic } \\
\text { Work Discipline } \\
\text { Organization } \\
\text { Commitment } \\
\text { Performance }\end{array}$ & $\begin{array}{l}\text { Work Ethic }- \text { Performance Not Significant } \\
\text { Work Dicipline }- \text { Performance Significant } \\
\text { Organitation Commitment } \quad-\text { Performance } \\
\text { Significant }\end{array}$ \\
\hline 5 & $\begin{array}{l}\text { (Handayaningsih } \\
\& \quad \text { Ernawati, } \\
\text { 2012) }\end{array}$ & $\begin{array}{l}\text { Discipline } \\
\text { Leadership } \\
\text { Work motivation } \\
\text { Welfare }\end{array}$ & $\begin{array}{l}\text { Discipline - Motivation Significant } \\
\text { Leadership - Motivation Significant } \\
\text { Welfare - Motivation Significant }\end{array}$ \\
\hline 6 & $\begin{array}{l}\text { (Riyaniningsih } \\
\& \text { Triyaningsih, } \\
\text { 2010) }\end{array}$ & $\begin{array}{l}\text { Discipline } \\
\text { Remuneration } \\
\text { Leader's model } \\
\text { Work motivation }\end{array}$ & $\begin{array}{l}\text { Dicsipline - Motivation Not Significant } \\
\text { Remuneration - Motivation Significant } \\
\text { Leader's model - Motivation Significant }\end{array}$ \\
\hline 7 & $\begin{array}{l}\text { Utin Wigiarti } \\
\text { dan Endang } \\
\text { Hendrayanti } \\
\text { (2012) }\end{array}$ & $\begin{array}{l}\text { Satisfaction } \\
\text { Dicipline } \\
\text { Motivation }\end{array}$ & $\begin{array}{l}\text { Satisfaction - Motivation Significant } \\
\text { Discipline - Motivation Significant }\end{array}$ \\
\hline 8 & $\begin{array}{l}\text { (Mudayana, } \\
\text { 2010) }\end{array}$ & $\begin{array}{l}\text { Motivation } \\
\text { Workload } \\
\text { Performance }\end{array}$ & Motivation - Performance Significant \\
\hline 9 & (Setiawan, 2015) & $\begin{array}{l}\text { Work motivation } \\
\text { Performance }\end{array}$ & Work motivation - Performance Significant \\
\hline 10 & $\begin{array}{l}\text { (Saputri, } \\
\text { Fudholi, \& } \\
\text { Sumarni, 2014) }\end{array}$ & $\begin{array}{l}\text { Work motivation } \\
\text { Organization Culture } \\
\text { Performance }\end{array}$ & $\begin{array}{l}\text { Work motivation }- \text { Performance Significant } \\
\text { Organization Culture } \quad-\quad \text { Performance } \\
\text { Significant }\end{array}$ \\
\hline 11 & (Riyadi, 2011) & $\begin{array}{l}\text { Financial Compensation } \\
\text { Leadership Style } \\
\text { Work Motivation } \\
\text { Performance }\end{array}$ & $\begin{array}{l}\text { Financial Compensation - Work motivation } \\
\text { Not Significant } \\
\text { Leadership Style - Work motivation } \\
\text { Significant } \\
\text { Financial Compensation - Performance Not } \\
\text { Significant } \\
\text { Leadership Style - Performance Significant } \\
\text { Work Motivation - Performance Significant }\end{array}$ \\
\hline 12 & $\begin{array}{l}\text { (Wijaya \& } \\
\text { Andreani, 2015) }\end{array}$ & $\begin{array}{l}\text { Compensation } \\
\text { Motivation } \\
\text { performance }\end{array}$ & $\begin{array}{l}\text { Compensation - Performance Significant } \\
\text { Motivation - Performance Significant }\end{array}$ \\
\hline 13 & $(P \& S, 2016)$ & $\begin{array}{l}\text { Motivation } \\
\text { Stress } \\
\text { Compensation } \\
\text { Performance }\end{array}$ & $\begin{array}{l}\text { The regression model created showed the } \\
\text { relationship between the benefits of } \\
\text { compensation, motivation, stress and job } \\
\text { performance. This model indicated the positive } \\
\text { impact of compensation and motivation on } \\
\text { performance, while stress had a significant } \\
\text { negative impact. }\end{array}$ \\
\hline
\end{tabular}




\begin{tabular}{|c|c|c|c|}
\hline 14 & $\begin{array}{l}\text { (Boye } \\
\text { Kuranchie- } \\
\text { Mensah \& } \\
\text { Amponsah- } \\
\text { Tawiah, 2016) }\end{array}$ & $\begin{array}{l}\text { Employee Motivation } \\
\text { Work Performance }\end{array}$ & $\begin{array}{l}\text { Intrinsic Motivation-Work Performance. } \\
\text { The null hypothesis was rejected that there } \\
\text { was no difference in the intrinsic motivation of } \\
\text { the mining company sample and it can be } \\
\text { concluded that there are significant differences } \\
\text { observed in the scores on intrinsic motivation } \\
\text { accoding to the education level of the } \\
\text { respondents. } \\
\text { Extrinsic Motivation and Work Performance. } \\
\text { The null hypothesis was therefore rejected at } \\
\text { the } 5 \% \text { level of significance, which means that } \\
\text { further analysis cannot be done on the average } \\
\text { score on extrinsic motivation because its score } \\
\text { was almost the same at all levels of education. }\end{array}$ \\
\hline 15 & $\begin{array}{l}\text { (Rokhmawati \& } \\
\text { Kuncowati, } \\
\text { 2018) }\end{array}$ & $\begin{array}{l}\text { Communication } \\
\text { Work Discipline } \\
\text { Employee Performance }\end{array}$ & $\begin{array}{l}\text { Communication - Employee } \text { Performance } \\
\text { Significant } \\
\text { Work Discipline - Employee } \\
\text { Significant }\end{array}$ \\
\hline
\end{tabular}

2.5 Conceptual Framework

The conceptual framework of the study can be seen in Picture 1 below:

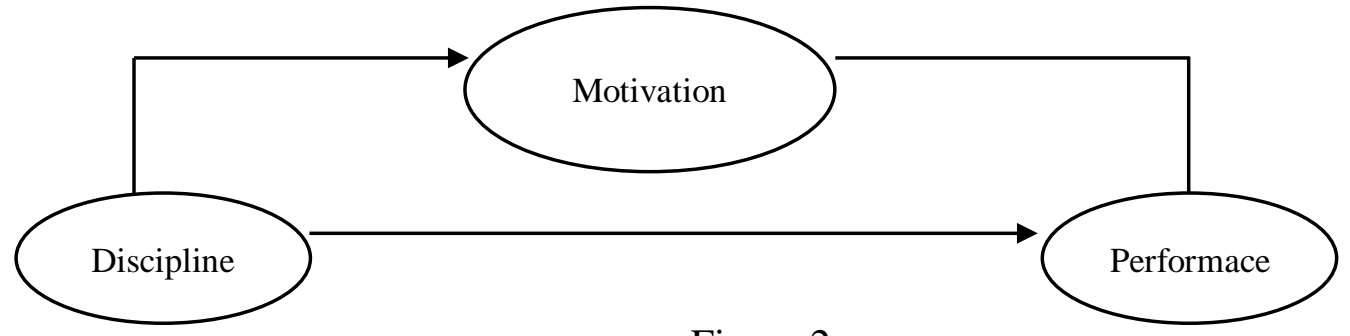

Figure 2

Conceptual Framework

2.6 The Hypothesis of The Research

Based on the framework above, the authors made three hypotheses which are:

a. It is assumed that discipline influences on motivation in Indragiri College of Economics (STIE-I) Rengat

b. It is assumed that discipline influences on Lecturer's performance in Indragiri College of Economics (STIE-I) Rengat

c. It is assumed that motivation influences on Lecturer's performance in Indragiri College of Economics (STIE-I) Rengat

\section{$3 \quad$ Methodologi / Material}

3.1 Research Design and Population

This research applied quantitative methods and all obtained data were processed by using PLS software. In this research, the population was 34 permanent lecturers Indragiri College of Economics (STIE-I) Rengat

\subsection{Variables and Operational Definitions}

Every lecturer in Indragiri College of Economics (STIE-I) Rengat should understand and figure out their Principal Task as a lecturer so that their performance would to improve. The main tasks of a lecturer in Indragiri College of Economics (STIE-I) Rengat based on the Statute of article 48 are:

(1) Every lecturer has to carry out education and teaching activities according to the authority of his academic position level. 
(2) Every lecturer has to carry out research activity in the context of education and teaching or in the activities of science development according to the authority of his academic position level.

(3) Every lecturer has to carry out community service activities in the context of education and teaching or in other activities that support the implementation of general government tasks and the development according to the authority of his academic position level.

In conducting this research, researchers used 3 variables consisting of disciplinary variables, motivation variables and performance variables. Motivation is an enforcement that drives the realization of a behavior in order to achieve the satisfaction. (Suwatno and Priansa, 2014: 172).

The indicators of work motivation according to Noor and Gofur (2009:156) are:

1. The desires to have achievement

2. The desires to make improvement.

3. The desires to make changes

4. The desires to always improve the work ability

5. The desires to have work knowlegde

According to Singodimedjo (2002) cited by Sutrisno (2010: 86) discipline is the attitude of someone's willingness and compliance to abide and obey the norms of regulations prevailing around it.

The indicators of discipline according to Hasibuan (2013: 194) are:

1. Purpose and Ability

2. The Examplary Leadership

3. Remuneration

4. Justice

5. Waskat

6. Penalty / Punishment

7. Firmness

8. Human relationship

Employee performance (work performance) is the result of work both in quality and quantity achieved by an employee in carrying out his duties in accordance with the responsibilities given to him. (Mangkunegara, 2014: 9).

The performance work indicators according to Sutrisno (2010) in Hamali (2016:119) are:

1. The Result of Work

2. Work Knowledge

3. Initiative

4. Mental Dexterity

5. Attitudes

6. Time and Attendance Disciplines

\section{$4 \quad$ Results and Discussions}

4.1 Validity Test

Validity test was used to measure the validity of quisionnaire. In this study, the validity test was carried out with a correlation between the scores of the question items with the total construct score or variable; then they were compared with the number 0.7. If the correlation between the questionnaire score and the total variable score was equal to 0.7 or more (at least 0.7 ), then the instrument item was declared valid. The results of the validity test of each variable using the PLS software program are shown in Figure 2. 


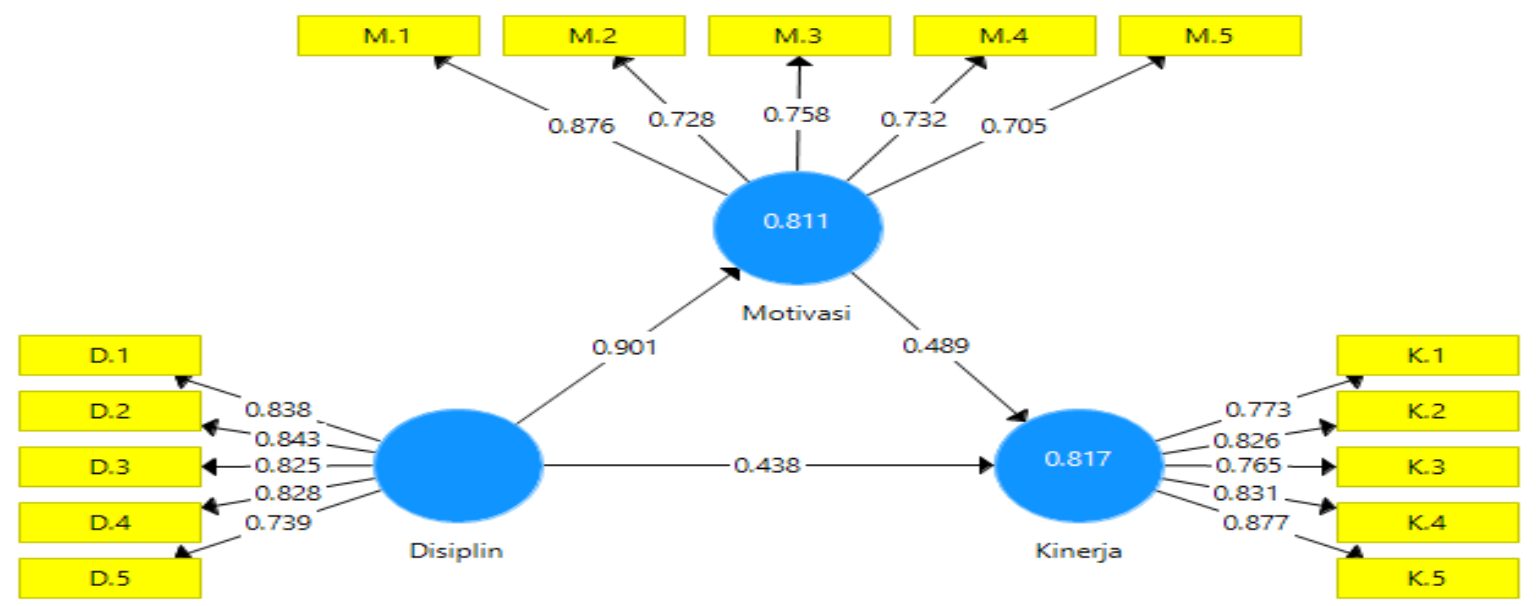

Gambar 3 Validity Test

From the picture above it can be seen that the calculated $\mathrm{R}$ score was greater than 0.7 so it can be concluded that all questions were valid.

\subsection{Reability Test}

A questionnaire was said to be reliable if a person's answer on a question was consistent or stable over time. Reliability variables were determined based on the Cronbach alpha score, if the Cronbach alpha score was greater than 0.7 , then the variable was reliable.

The results of the reliability test of each variable using the PLS program are shown in table 2 below:

Table 2 : Reliability Test on Research Variables

\begin{tabular}{|c|c|c|c|c|c|c|}
\hline Variables & $\begin{array}{c}\text { Number } \\
\text { of } \\
\text { Questions }\end{array}$ & $\begin{array}{c}\text { Cronbach's } \\
\text { Alpha } \\
\text { Scores }\end{array}$ & $\begin{array}{c}\text { rho_A } \\
\text { Scores }\end{array}$ & $\begin{array}{c}\text { Composite } \\
\text { Reliability } \\
\text { Scores }\end{array}$ & $\begin{array}{c}\text { Minimal } \\
\text { Scores }\end{array}$ & Information \\
\hline Discipline & 5 & 0,874 & 0,882 & 0,908 & 0,7 & Reliable \\
\hline Motivation & 5 & 0,873 & 0,876 & 0,908 & 0,7 & Reliable \\
\hline Performance & 5 & 0,817 & 0,822 & 0,873 & 0,7 & Reliable \\
\hline
\end{tabular}

From table 2 above, it can be seen that all research variables, Cronbach's Alpha, rho_A and Composite Reliability are bigger than 0.7 . So it is concluded that all research variables are reliable.

4.3 Hypothesis Testing

By using PLS in processing the data, the obtained results are:

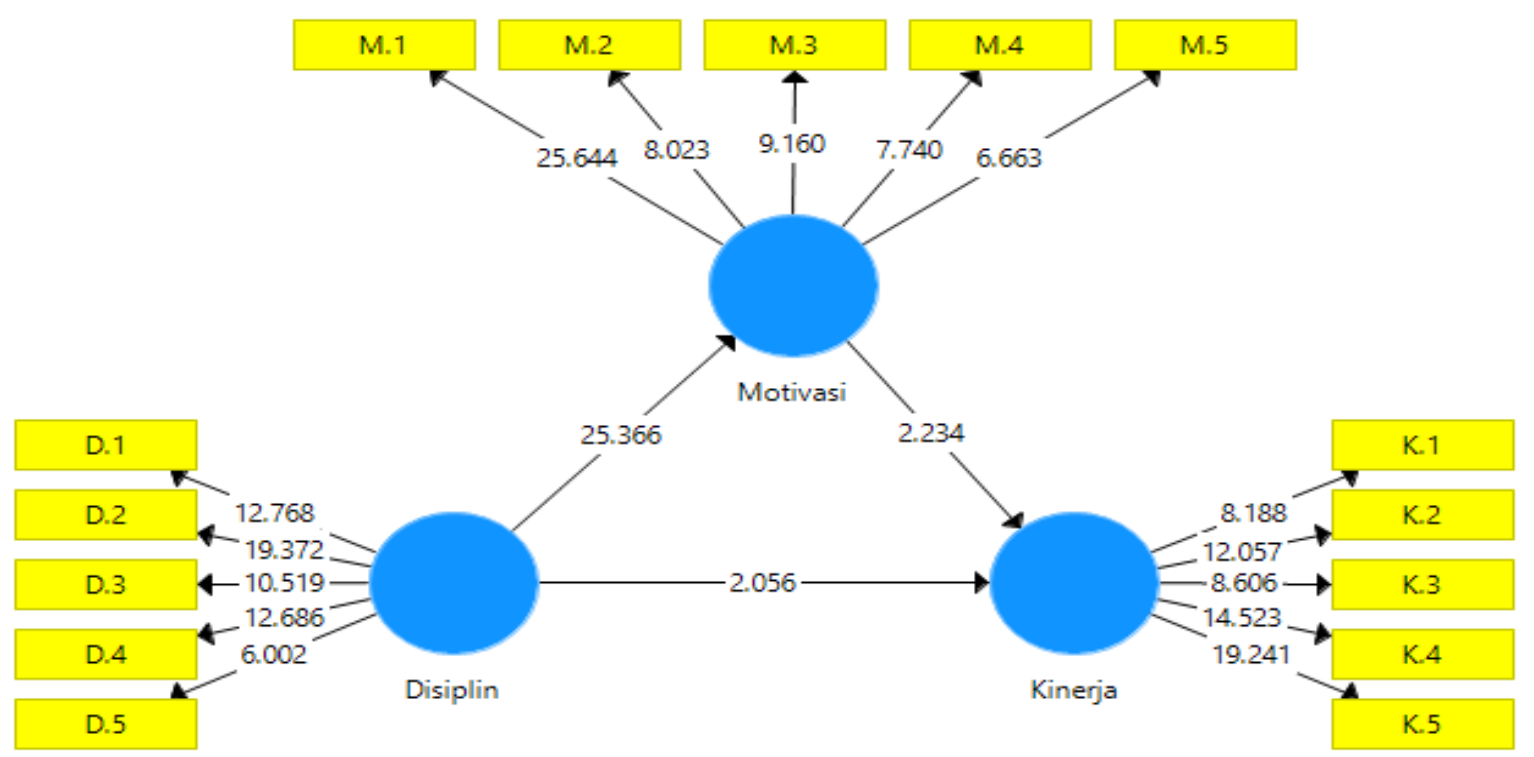

Hyphothesis Testing

Table 3 : Hypothesis Testing 


\begin{tabular}{l|r|r|r|r|r|} 
& Original Sample (0) & Sample Mean (M) & Standard Deviation (STDEV) & TStatistics (|O/STDEV) & P Values \\
\hline Disiplin -> Kinerja & 0.438 & 0.446 & 0.213 & 2.056 & 0.040 \\
\hline Disiplin -> Motivasi & 0.901 & 0.899 & 0.036 & 25.366 & 0.000 \\
\hline Motivasi $\rightarrow$ Kinerja & 0.489 & 0.479 & 0.219 & 2.234 & 0.026 \\
\hline
\end{tabular}

Sources : PLS Data Process

Based on the t- Tabel score amounted to 2,036, so that the statistics are:

\section{H1. The Influence of Discipline on Motivation}

Based on figure 3 above, it was obtained that the t-Count score of discipline on motivation is 25,366 while the $\mathrm{t}$-Table score is 2,036 so that $\mathrm{t}$-Count $>\mathrm{t}$-Table which is $25,366>2,036$. It can be concluded that disciplines had significant impact on motivation, so that the hypothesis test accepted $\mathrm{H}_{1}$ and rejected $\mathrm{H}_{0}$.

\section{H2. The Influence of Discipline on Performance}

Based on figure 3 above, it was obtained that t-count score of discipline on performance is 2.056 while the $\mathrm{t}$-table score is 2.036 so that the t-Count> t-Table which is 2.056>2.036. It can be concluded that the disciplines had significant impact on performance, so that the hypothesis test accepted $\mathrm{H}_{2}$ and rejected $\mathrm{H}_{0}$.

\section{H3. The Influence of Motivation on Performance}

Based on figure 3 above, it was obtained that the t-Count score of motivation on performance is 2,234 while the $\mathrm{t}$-Tabel score is 2,036 so that $\mathrm{t}$-Count $>\mathrm{t}$-Table which is $2,234>2,036$. It can be concluded that motivations have significant impact on performance, so that the hypothesis test accepted $\mathrm{H}_{3}$ and rejected $\mathrm{H}_{\mathrm{O}}$.

Based on the results of the study, the authors found that the motivation variable turned out to be an intervening variable among disciplines on performance, as shown in table 4 below:

Tabel 4 : Motivasi sebagai Variabel Intervening

$\begin{array}{rrrrrr} & \text { Original Sample (0) } & \text { Sample Mean (M) } & \text { Standard Deviation (STDEV) } & \text { TStatistics (IO/STDEV) } & \text { PValues } \\ \text { Disiplin } \rightarrow \text { Motivasi } \rightarrow \text { Kinerja } & 0.441 & 0.429 & 0.196 & 2.248 & 0.025 \\ \text { : PLS Data Processed } & & & & & \end{array}$

Based on figure 4 above, it is known that motivation can be intervening variable among discipline variable on performance, it can be seen by compaing the t-Count score is 2,248 which is bigger than t-Table score 2,036. Therefore it can be concluded that the results of this research show the disciplines have significant impact on performance which is mediated by motivation.

\subsection{Discussion}

Based on research, it is known that discipline has a significant effect on motivation, and the results of this research are supported by previous research conducted by Handayaningsih and Ernawati (2012) and Wigiarti and Hendrayanti (2012) which stated that discipline has a significant effect on work motivation. Meanwhile, in the influence of discipline on the lecturers' performance, it was obtained that the result is also significant, this result is the same as the research conducted by Rinaldi (2016), Jariah (2016) Rinaldi (2016), likewise Timbuleng and Sumaraw (2015) stated that the discipline had an effect and significant on performance. Afterwards, in the influence of motivation on the lecturers' performance, it is obtained that the results also have a significant influence and this has been raised by previous research by Mudayana (2010), Setiawan (2015), Saputri, Fudholi and Sumarni (2014), Riyaldi (2011), and Wijaya and Andreani ( 2015) stated that motivation has an effect and significant on performance. 
5.1 Conclusions

The purpose of the research study was to determine the influence of discipline on motivation, the influence of discipline on performance, the influence of motivation on performance and the infuence of discipline on motivation mediated by performance. Based on the results of the discussion above, the conclusions of this research are:

1. There are significant effects between discipline on motivation, discipline on performance and motivation on performance, these results are obtained based on data processing using PLS where the score of t-Count for each variable is bigger than the score of the t-Table.

2. Motivation is an intervening variable on the relationship between discipline variables on lecturer performance, the results of the study show that discipline has a significant effect on performance mediated by Motivation. This result is obtained based on data processing using PLS where the t-Count score is bigger than the t-Table score.

\subsection{Suggestions}

The suggestions that the researchers provide are:

1. Giving motivation and increasing lecturer discipline must always be improved and sustainable because it has a significant influence on the performance of lecturers.

2. The leader's attention towards increasing the provision of motivation and enforcement of discipline must continually be given so that the lecturer's performance gets better.

3. The leader must be firm in every semester to give punishment to every lecturer who makes a mistake and gives rewards to lecturers who have the best performance.

\section{Reference}

[1] Boye Kuranchie-Mensah, E., \& Amponsah-Tawiah, K. (2016). Employee motivation and work performance: A comparative study of mining companies in Ghana. Journal of Industrial Engineering and Management, 9(2), 255. doi: 10.3926/jiem.1530

[2] Handayaningsih, K., \& Ernawati. (2012). Pengaruh Disiplin Dan Kepemimpinan Terhadap Motivasi Kerja Pegawai Dengan Kesejahteraan Sebagai Variabel Moderasi. Jurnal Manajemen Sumberdaya Manusia, 6(1), 13.

[3] Hasibuan, S.P. Malayu. 2013. Manajemen Sumber Daya Manusia, cetakan ketujuh belas. PT Bumi Aksara, Jakarta.

[4] Hamali, Arif Yusuf. 2016. Pemahaman Manajemen Sumber Daya Manusia (Strategi Mengelola karyawan). PT. Buku Seru. Yogyakarta.

[5] Mangkunegara. Anwar Prabu. 2014. Evaluasi Kinerja SDM. PT. Refika Aditama. Bandung.

[6] Mudayana, A. A. (2010). Pengaruh Motivasi Dan Beban Kerja Terhadap Kinerja Karyawan Di Rumah Sakit Nur Hidayah Bantul. Kesmas UAD, 4(2).

[7] Noor Fuad dan Gofur Ahmad. 2009. Integrated Human Resources Development, berdasarkan Pendekatan CB-HRM, TB-HRM, CBT, dan CPD. PT. Grasindo. Jakarta.

[8] Notoatmodjo Soekidjo. 2009. Pengembangan Sumber Daya Mnausia. Penerbit PT. Rineka Cipta. Jakarta.

[9] P, P. N., \& S, S. G. (2016). Effects Of Motivation, Stress And Compensation Benefits On Employee Performance In It Professionals. International Journal of Advanced Research, 4(1), 9.

[10] Rinaldi, M. (2016). Pengaruh Disiplin Kerja Dan Etos Kerja Serta Gaya Kepemimpinan Situasional Terhadap Kinerja Pegawai Di Kantor Badan Penanggulangan Bencana Daerah Kota Palu. e Jurnal Katalogis, 4(10), 8.

[11] Rinaldi, U. (2016). Dampak Disiplin, Etos Kerja Dan Iklim Organisasi Terhadap Kinerja (Studi Kasus Pada PT Sentosa Pontianak). Jurnal Eksos, XI(1), 10.

[12] Riyadi, S. (2011). Pengaruh Kompensasi Finansial, Gaya Kepemimpinan, dan Motivasi Kerja Terhadap Kinerja Karyawan pada Perusahaan Manufaktur di Jawa Timur. Jurnal Manajemen Dan Kewirausahaan, 13(1), 6. 
[13] Riyaniningsih, S. P., \& Triyaningsih, S. (2010). Pengaruh Disiplin, Balas Jasa Dan Keteladanan Pimpinan Terhadap Motivasi Kerja Pegawai Dinas Kesehatan Kabupaten Sukoharjo. Jurnal Manajemen Sumberdaya Manusia, 4(2), 11.

[14] Rokhmawati, H. N., \& Kuncowati, H. (2018). The Influence of Communication and Work Discipline on the Employee Performance (A Case Study of Employee Performance of Dwi Arsa Citra Persada Foundation in Yogyakarta \& Indonesia). Researchers World : Journal of Arts \& Science and Commerce(RWJASC), IX(2), 06. doi: 10.18843/rwjasc/v9i2/02

[15] Saputri, L. T., Fudholi, A., \& Sumarni. (2014). Pengaruh Motivasi Kerja Dan Budaya Organisasi Terhadap Kinerja Karyawan. 4(1), 6.

[16] Setiawan, K. C. (2015). Pengaruh Motivasi Kerja Terhadap Kinerja Karyawan Level Pelaksana Di Divisi Operasi PT. Pusri Palembang. Jurnal Psikologi Islami, 1(2), 12.

[17] Shaleh Mahadin. 2018. Komitmen Organisasi terhadap Kinerja Pegawai. Penerbit Aksara Timur. Makasar.

[18] Sinungan, Muchdarsyah. 2009. Produktivitas, apa dan bagaiamana. PT. Bumi Aksara. Jakarta.

[19] Simamora Henry. 2004. Manajemen Sumber Daya Manusia. Penerbit Sekolah Tinggi Ilmu Ekonomi YKPN. Yogyakarta.

[20] Sunyoto, Danang. 2013. Manajemen Sumber Daya Manusia. CAPS. Yogyakarta.

[21] Sutrisno, Edi. 2010. Manajemen Sumber Daya Manusia. Edisi 1 cetakan ke dua. Kencana. Jakarta.

[22] Suwatno dan Priansa, Donni Juni. 2014. Manajemen SDM dalam Organisasi Publik dan Bisnis. Alfabeta. Bandung.

[23] Timbuleng, S., \& Sumarauw, J. S. B. (2015). Etos Kerja, Disiplin Kerja, Dan Komitmen Organisasi Pengaruhnya Terhadap Kinerja Karyawan Pada PT Hasjrat Abadi Cabang Manado. Jurnal EMBA, 3(2), 10.

[24] Wijaya, T., \& Andreani, F. (2015). Pengaruh Motivasi Dan Kompensasi Terhadap Kinerja Karyawan Pada PT Sinar Jaya Abadi Bersama. AGORA, 3(2), 9.

[25] Wukir. 2013. Manajemen Sumber Daya Manusia Dalam Organisasi Sekolah. Penerbit Multi Presindo. Yogyakarta 